\title{
Shadow Economy and its Impact on Demand at the Investment Market of the Country
}

\author{
Yuriy Bilan, Tatiana Vasylieva, Sergij Lyeonov, Inna Tiutiunyk
}

\section{A B S T R A C T}

Objective: The objective of the research is to study the link between drivers of the shadow economy and the demand level on the investment market.

\begin{abstract}
Research Design \& Methods: Based on the Shapiro-Wilk test, the normality of capital investment distribution and the shadow economy level of the European Union countries and Ukraine are evaluated. Spearman and Shapiro-Wilk tests are used to identify the most relevant indicators of impact.
\end{abstract}

Findings: The analysis of the changing dynamics regarding the capital investment volume and the shadow economy level in Ukraine and the EU countries during 2010-2016 shows that there is an inverse link between them - the growth of the shadow economy has a negative impact on the capital investment volume in the country.

Implications \& Recommendations: This research proves significant influence of the shadow economy on the demand level on the investment market and underlines the necessity to review the current state policy to stimulate the demand on the investment market from the viewpoint of the most relevant shadow drivers.

Contribution \& Value Added: The scientific contribution of the article is that existing research on the impact of shadow economy on the economic development of countries remains fragmented, as well as studies assessing its effect on a country's investment attractiveness. The constructed econometric model may provide some insight into better understanding of the most influential factors affecting a country's investment attractiveness and the immediate response to it.

\begin{tabular}{ll}
\hline Article type: & research article \\
& shadow economy; investment activities; money laundering; legalisa- \\
Keywords: & tion; corruption \\
JEL codes: & F63, G17, H3,K220
\end{tabular}

Received: 27 November $2018 \quad$ Revised: 28 February $2019 \quad$ Accepted: 5 March 2019

\section{Suggested citation:}

Bilan, Y., Vasylieva, T., Lyeonov, S., \& Tiutiunyk, I. (2019). Shadow Economy and its Impact on Demand at the Investment Market of the Country. Entrepreneurial Business and Economics Review, 7(2), 27-43. https://doi.org/10.15678/EBER.2019.070202 


\section{INTRODUCTION}

Under conditions of the financial resources deficit, internal and external investments are significant tools to fasten rates of economic growth and to create a possibility to move to the qualitatively new level of a country's development (Skare \& Porada-Rochon', 2019).

Specialists of the United Nations Conference on Trade and Development define an increase in the foreign direct investment (FDI) volumes and qualitative transformation of their flows as a key dominant to achieve Millennium Development Goals. Such goals have an obvious social and economic focus, so that is why today the important task for governments of all countries is to set a clear and stable relationship in the investing sphere.

Investments are observed as factors of the technical and technological production renovation, structural shifts in the national economy, an increase in the economic qualitative indicators at the micro and macro levels, a guarantee of a country's macroeconomic stability (Rahimi, 2016; Damoska Sekuloska, 2018; Nazarczuk \& Krajewska, 2018; Do \& Park, 2018; Špička, 2018). The formation of the country's favorable investment environment, being under the influence of external and internal factors, is considered to be the basis for investment attractiveness of any country (Cheba \& Szopik-Depczyńska, 2017). One of the biggest destructive factors is the shadow economy (Al-Sadig, 200; Blajer-Gołębiewska \& Kos, 2016; Bobenič Hintošová et al., 2018; Kostyuchenko et al., 2018; Leonov et al., 2014; 2018; Vasilyeva, 2013, 2016, 2018).

According to United Nations Office on Drugs and Crime (2018), the annual amount of money laundering is equal to $2-5 \%$ of the world GDP and is said to cause a significant impact on the economic development indicators of a country. It is observed by investors as one of the main threats to effective capital investment.

Thus, the performed analysis shows that there is a great changeability and instability of the FDI volumes in the majority of the analysed countries and updates the necessity to define the most significant factors of impact on them.

Therefore, the main objective of the article is to measure the impact made by some drivers of the shadow economy (SE) on the investment activity in Ukraine and the EU countries. While identifying them, we use statistical methods such as the Shapiro-Wilk test, Spearman's rank correlation, econometric modelling.

The remainder of the article is arranged as follows. In the second section, we analyse the current studies of the shadow economy impact on investment activity in a country. In the third section the shadow economy drivers which have the greatest impact on the demand level at the country's FDI are analysed. In the fourth section, we present a correlation analysis between the volume of capital investment and selected variables. Based on the set dependencies, a mathematic model is built. In section 5, we present our conclusions and suggestions for further research.

\section{LITERATURE REVIEW}

The degree of the interrelation between the shadow economy and a country's investment attractiveness has been actively studied by representatives of the world countries' international economic community. The available theoretical and empirical studies have not provided an unambiguous answer to this problem. One of the reasons for such a situation 
is the fact that the susceptibility level of a country's investment development indicators from the shadow economy level is defined not only by the objective reasons of their interrelation but also by the economic development stability, the economic security level, investment potential, the existence of an economic or political crisis in the country. On the other hand, there are many scientific works which deal with the determinants of the shadow economy, the correlation level evaluation between general indicators of the shadow economy and direct foreign investment volume. However, nowadays, there are not detailed investigations of the impact made by separate factors of the shadow economy on the investment level and identification of the most influential ones.

\section{Determinants of Shadow Economy}

The scientific literature has a great variety of approaches to identify the most influential determinants of the shadow economy, which differ with the impact factors and results of their action degree and directions assessment.

Many authors (Sookram et al., 2009; Williams, \& Nadin, 2012) studied the shadow economy in terms of its relationship with the labour market. According to Wiseman (2013), employment problems in the country, high level of unemployment become the reasons for an increase in informal employment. While studying the labour market in Poland, Cichocki and Tyrowicz (2010) made conclusions that on the one hand, the shadow economy factors are taxation disorders at the official labour market, and on the other hand, the absence of the demand for some professions on the official market.

Another factor, observed in terms of the influence in the shadow economy, is the confidence level in the government and good governance. Teobaldelli and Schneider (2013), Ipatov et al. (2018) confirmed that countries where the fiscal regulation of the economy is carried out on a democratic base, had lower shadow economy.

Based on the examples of foreign experience, Krumplyte (2008) demonstrates that countries with a high tax burden (52-55\%) are more competitive and have a small amount of the shadow economy (Sweden, Denmark, Finland). Countries with a relatively low tax burden (up to $20 \%$ ) have the shadow economy of over $60 \%$ of GDP (Georgia, Mexico).

In general, for most industrial countries the following factors influence the level of the shadow economy (Enste, 2015): tax burden and excessive contributions of social insurance; frequency and intensity of the regulation of officially recorded economy, extremely strict regulation of the labour market with untimely retirement, growing unemployment rate and limitation of possible work hours per week, which define the search of illegal jobs. Usually, countries with a high level of the shadow economy demonstrate a low level of being ready to pay taxes, defined by corruption, tolerance of the state, and low respect and loyalty to public organisations. Analysing the countries of the Central and Eastern Europe, including the Baltic states, scientists (Schneider, 2007) point to other reasons which specify the shadow economy: incompetence of official institutions (legal acts, bureaucracy, judicial practice); corruption which undermines the confidence in government; weak realisation of legislation, impossibility or unwillingness to protect the property rights; high expenses for business development and burden on business administration; low probability of the fact that it is possible to avoid it if one avoids paying taxes or doing illegal work; extremely high bureaucracy.

The level of the shadow economy in Lithuania during 2000-2011 is explained by such factors as labour power velocity, the volume of the international trade, the private sector 
crediting and business freedom index. In Estonia and Lithuania, the limitations of the private sector credit are determinant factors which influence the scales of the shadow economy.

\section{Drivers of Shadow Economy and Investment Activities}

There are various empirical studies on the link between separate elements in the shadow economy and the investment activities. Some of them have argued that the shadow economy impeded the investment growth. However, there are a lot of studies identifying the shadow economy as an important determinant of the FDI attracted by a country (Wei, 2000; Cleeve, 2008; Al-Sadig, 2007; Asiedu, 2006; Morrissey et al., 2012; Omidie et al., 2017, Formankova et al., 2018; Nunes et al., 2017).

According to the first hypothesis, the shadow economy negatively affects the level of social and economic development of a country, distorts the indicators of official statistics and therefore would lead to ineffective macroeconomic policy. Abed and Davoodi (2002) study a negative impact of the shadow economy on the FDI for 24 transition countries.

The similar results of the negative influence, made by corruption, on total FDI in Eastern Europe and the former Soviet Union are provided by Smarzynska and Wei (2000). Lambsdorff and Cornelius (2000) investigated the negative impact of the shadow economy on FDI for the African countries. They found that corruption deterred FDI more than local investments.

On the other hand, the shadow economy is characterised by a range of positive effects on investment activity in a country. Based on the data of 73 countries, Egger and Winner (2005) made a conclusion that foreign companies being interested in making FDI might use various channels of money laundering, corruption schemes in order to receive special conditions.

Abror (2015) analysed the regional effect of shadow economies on FDI for 40 countries divided into four groups (Europe, South \& North America, Africa \& Middle East, Asia \& Oceania) over the period from 1999 to 2009 using a panel data method. He made a conclusion that the European countries have a statistically significant and negative relationship between the SE and FDI. South and North America countries have a statistically significant and positive relationship between them. Janicki (2004) concluded that the trade openness was the most important determinant of FDI for eight EU countries (Bulgaria, the Czech Republic, Estonia, Hungary, Poland, Slovakia, Slovenia, Romania) and Ukraine. The salary level had also a significant influence. The lower it was, the higher interest grew among foreign investors.

Riedl (2009) defined the flowing factors of influence on the direct foreign investments for new EU countries (The Czech Republic, Estonia, Hungary, Latvia, Lithuania, Poland, Slovakia and Slovenia): GDP, concentration of the industry and agglomeration had a positive impact, the salary level - negative. For such countries as the Czech Republic, Hungary, Poland, etc., Demirhan (2008) defined that trade openness positively influences FDI, inflation and tax rate - negatively.

A great number of researchers suggests that FDI inflows in the developing economies favourably related to the openness to trade (Zdziarski, Światowiec-Szczepańska, Troilo, \& Małys, 2017). Addison and Heshmati (2003) examined the impact of FDI in almost 50 developing countries using exports and imports as a percentage share of GDP. Their findings indicate that there is a positive and significant relationship between both of them. 
Based on the analysis of the national currency exchange rate against the US dollar and direct foreign investments volume, Udomkerdmongkol et al. (2006) concluded that there was a positive significant relationship between them.

However, taking into account the above variety of impact of the shadow economy drivers on the investment attractiveness level in a country, provided by the differently directed level of their manifestation, by various time horizons, degree of consequences, formation of the mathematic model regarding the factorial features impact on the investment volumes in the country, can be an effective tool to identify the most influential factors and can be the criterion to make decisions while investigating the preventive measures oriented to increase demand and supply on the investment market.

\section{MATERIAL AND METHODS}

The study regarding changes of the tendencies in the investment activity indicators in the country and shadow withdrawals of funds through comparison of the changing dynamics regarding Global Foreign Direct Investment Country Attractiveness (GFDICA) and Basel Anti-Money Laundering Index (BAMLI) for the EU countries and Ukraine during 2015-2018 is shown in Figure 1.

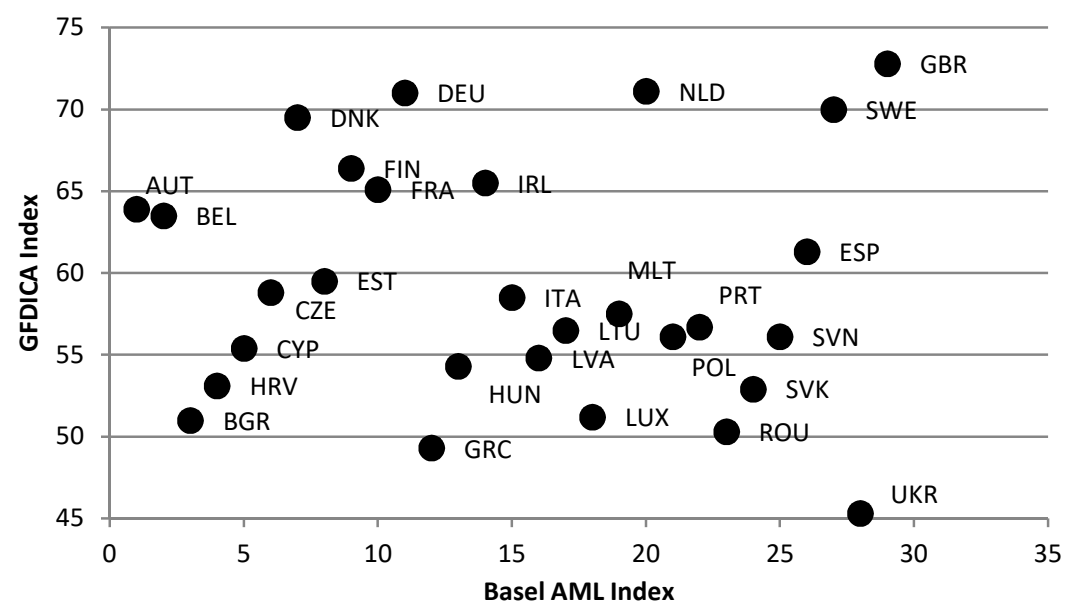

AUT - Austria, BEL - Belgium, BUL - Bulgaria, HRV - Croatia, CYP - Cyprus, CZE - Czech Republic, DNK - Denmark, EST - Estonia, FIN - Finland, FRA - France, DEU - Germany, GRC - Greece, HUN - Hungary, IRL - Ireland, ITA - Italy, LVA - Latvia, LTU - Lithuania, LUX - Luxembourg, MLT - Malta, NLT - Netherlands, POL - Poland, PRT - Portugal, ROU - Romania, SVK - Slovak Republic, SVN - Slovenia, ESP - Spain, SWE - Sweden, UKR - Ukraine, GBR - United Kingdom

Figure 1. Comparison of the average GFDICA and BAMLI in the EU countries and Ukraine in 2015-2018

Source: own elaboration based on the Global Foreign Direct Investment Country Attractiveness Index data available at http://www.fdiattractiveness.com/; International Centre for Asset Recovery data available at https://index.baselgovernance.org/

According to the results of the analysis, one can conclude that most EU countries have average indicators. Austria, Belgium, Denmark, Germany are characterised by the highest level of the investment attractiveness and low volumes of the shadow financial flows. 
A number of countries, among which the United Kingdom, Sweden, Netherlands have high indicators of the investment attractiveness and the worst indicators of Basel AML Index among the analysed countries. Ukraine, as only one country, which is not in the EU, has the worst analysed indicators.

Based on the above related literature, in this article we study the degree and nature (positive or negative) of the impact, made by some factor indicators of the shadow economy, on the direct foreign investment level for highly developed countries (EU countries) and those, which try to join the EU (Ukraine).

First, we will analyse the basic static indicators characterising the stability of the analysed indicators - standard deviation, the maximum and minimum value (Table 1).

Table 1. Descriptive statistics of the used variables in GDP and Money Laundering in the period from 2004 to 2016

\begin{tabular}{|c|c|c|c|c|c|c|c|}
\hline Country & $\begin{array}{c}\text { Descriptive } \\
\text { statistics }\end{array}$ & FDI & ML & Country & \begin{tabular}{|c|} 
Descriptive \\
statistics
\end{tabular} & GDP & ML \\
\hline \multirow{4}{*}{ Hungary } & Mean & 7725.4 & 6108 & \multirow{4}{*}{ Bulgaria } & Mean & \begin{tabular}{|l|}
1976.4 \\
\end{tabular} & 2382 \\
\hline & Std. Dev. & 27816.7 & 1586 & & Std. Dev. & 341.7 & 1326 \\
\hline & Min & 20934 & 2593 & & Min & 1656 & 681 \\
\hline & Max & 69816 & 8457 & & Max & 2707 & 5358 \\
\hline \multirow{4}{*}{ Sweden } & Mean & 6742.3 & 1688 & \multirow{4}{*}{ Estonia } & Mean & 1270 & 1434 \\
\hline & Std. Dev. & 11838.4 & 774 & & Std. Dev. & 960.6 & 227 \\
\hline & Min & 8624 & 815 & & Min & 714 & 1190 \\
\hline & Max & 32553 & 2725 & & Max & 2593 & 1921 \\
\hline \multirow{4}{*}{ Germany } & Mean & 65792.8 & 54605 & \multirow{4}{*}{ Ireland } & Mean & 68775 & 5908 \\
\hline & Std. Dev. & 23541.7 & 5992 & & Std. Dev. & \begin{tabular}{|l|l}
73211.4 \\
\end{tabular} & 2944 \\
\hline & Min & 19778 & 44412 & & Min & 3436 & 1944 \\
\hline & Max & 97481 & 62455 & & Max & 235356 & 9287 \\
\hline \multirow{4}{*}{ France } & Mean & 36116.2 & 43917 & \multirow{4}{*}{ Finland } & Mean & \begin{tabular}{|l|}
6956.5 \\
\end{tabular} & 453 \\
\hline & Std. Dev. & 13510.9 & 5061 & & Std. Dev. & 8994.0 & 224 \\
\hline & Min & 5810 & 37922 & & Min & 6008 & 235 \\
\hline & Max & 47336 & 53464 & & Max & 17244 & 928 \\
\hline \multirow{4}{*}{ Slovakia } & Mean & 2619.1 & 939 & \multirow{4}{*}{ Romania } & Mean & 3984.5 & 3545 \\
\hline & Std. Dev. & 2181.7 & 200 & & Std. Dev. & 1212.6 & 974 \\
\hline & Min & 362 & 633 & & Min & 2370 & \begin{tabular}{|l|}
1958 \\
\end{tabular} \\
\hline & Max & 5922 & 1268 & & Max & 6252 & 5284 \\
\hline \multirow{4}{*}{ Greece } & Mean & 2160.2 & 3836 & \multirow{4}{*}{ United Kingdom } & Mean & 78711.3 & 7468 \\
\hline & Std. Dev. & 1195.8 & 2034 & & Std. Dev. & 76658.1 & 697 \\
\hline & Min & 534 & 2571 & & Min & 27012 & 6288 \\
\hline & Max & 4022 & 9776 & & Max & 265811 & 8646 \\
\hline \multirow{4}{*}{ Ukraine } & Mean & 4563.3 & 12306 & \multirow{4}{*}{ Poland } & Mean & 13011.1 & 10937 \\
\hline & Std. Dev. & 2506.4 & 5258 & & Std. Dev. & \begin{tabular}{|l|}
6917.9 \\
\end{tabular} & 6190 \\
\hline & Min & 847 & 4380 & & Min & 795 & 651 \\
\hline & Max & 8175 & 21001 & & Max & 19776 & 17698 \\
\hline
\end{tabular}

Source: own calculations in Stata 1 based on World Bank data available at http://databank.worldbank.org/data/

The results of the calculations, pointing to a significant variation of the analysed indicators by years and a significant degree of their deviation of the average value, are shown 
in Table 1. The standard deviation indicator of the analysed countries is characterised by a substantial scope. Thus, if the value does not exceed 1000 for Bulgaria, Estonia according to the indicator of the foreign investment volume, for such countries as Germany, Ireland, United Kingdom, Hungary it exceeds 20000. The same situation is with the amounts of illegal money laundering abroad.

Within the framework of the research of the demand on the investment market, the regressive equation of dependence between resulting and factorial features can be shown as:

$$
\mathrm{D}(\mathrm{t})=\mathrm{d}_{0} \times \prod_{\mathrm{i}} \mathrm{u}_{\mathrm{i}}^{\mathrm{d}_{\mathrm{i}}}\left(\mathrm{t}-\mathrm{l}_{\mathrm{i}}\right)
$$

where:

$\mathrm{D}(\mathrm{t})$ - resulting feature of the econometric model, in t-period;

$\mathrm{d}_{0}, \mathrm{~d}_{1}$ - parameters of the regression equation, which are constant values;

$\mathrm{u}_{\mathrm{i}}$ - thei-factorial feature of the multiplicative regression model;

$l_{i}$ - lag, which complies with the i-factorial feature of the model.

Based on the above analysis, we will study the impact made by the drivers of the shadow economy in terms of their following groups (Table 2 ).

Table 2. Groups of drivers of the shadow economy

\begin{tabular}{|c|c|}
\hline Group of SE drivers & Indicators \\
\hline Tax system & $\begin{array}{l}\text { a number of tax payments }\left(u_{3}\right) \text {, the total tax burden on the business }\left(u_{17}\right) \\
\text { (Melnyk, 2018); }\end{array}$ \\
\hline Labour system & $\begin{array}{l}\text { the citizens' incomes volume }\left(u_{4}\right) \text {, the official level of unemployment }\left(u_{6}\right) \\
\left(\text { Rausser et al., 2018; Ipatov, 2018), real average salary }\left(u_{7}\right)(\text { Enste, 2015), }\right. \\
\text { level of the labour migration }\left(u_{14}\right)(G r e c o, 2018) \text {; }\end{array}$ \\
\hline The trade openness & $\begin{array}{l}\text { level of import and export }\left(u_{15}\right) \text {, the foregone earnings for export of goods } \\
\text { and services }\left(u_{24}\right) \text { and payment for import }\left(u_{12}\right)(B i l a n \text { et al., 2017; 2018), } \\
\text { which did not come, the volume of public debt }\left(u_{13}\right) \text {, the unregistered out- } \\
\text { flow of funds (removal of financial resource) (u23); }\end{array}$ \\
\hline Banking system & $\begin{array}{l}\text { weighted average interest rate by all interest-bearing tools }\left(u_{1}\right) \text {, the interest } \\
\text { rate for deposits }(u 9) \text {, interest rate for credits }\left(u_{10}\right) \text {, level of the deposit out- } \\
\text { flow }\left(u_{16}\right) \text {, number of the solvent banks }\left(u_{21}\right) \text {, official exchange rate of UAH } \\
\left.\text { in relation to the Euro }\left(u_{8}\right) \text { (Fernandes, } 2018\right) \text {; }\end{array}$ \\
\hline $\begin{array}{l}\text { Quality } \\
\text { of state regulations }\end{array}$ & $\begin{array}{l}\text { level of the legal system efficiency in the arbitrary regulation }\left(u_{22}\right) \text { (Djalilov, } \\
\left.2015 \text {; Ipatov et al., 2018), index of corruption }\left(u_{20}\right) \text {, level of inflation }\left(u_{19}\right),\right)_{1}, \\
\text { the yield of government securities at the primary market }\left(u_{2}\right) \text {; }\end{array}$ \\
\hline Industry development & $\begin{array}{l}\text { the quantity of the sold industrial production }\left(u_{5}\right) \text {, the share of the profitable } \\
\text { enterprises }\left(u_{18}\right) \text {. }\end{array}$ \\
\hline
\end{tabular}

Source: own study.

\section{RESULTS AND DISCUSSION}

In order to confirm the hypothesis regarding the link between the shadow economy and FDI, we compare changing tendencies of the given indicators during 2010-2016.

The complex analysis of the proper statistic information and determination of the time gaps between the quantitative values of the analysed indicators provide the possibility to obtain the econometric model which is relevant to the real economic system. In order to define the correlation coefficients, let us evaluate the distribution normality of the varying 
indicator via the Shapiro-Wilk test. The results of calculations, shown in Figure 2, demonstrate that most indicators have a normal distribution, however, some of them are not subordinated to the normal distribution law.

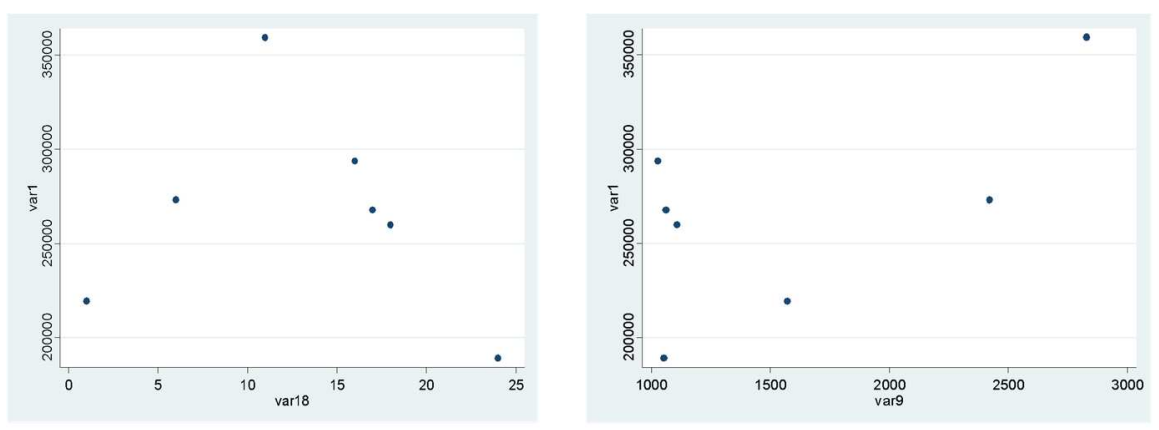

Figure 2. Evaluation of the distribution normality of indicators by Shapiro-Wilk test Source: own calculations in Stata 12.

The results from the evaluation of distribution normality of the shadow economy drivers are given in Table 2.

Table 2. Evaluation of distribution normality of the shadow economy drivers by Shapiro-Wilk test

\begin{tabular}{|l|c|c|c|c|c|c|c|c|}
\hline \multirow{2}{*}{ Variable } & \multicolumn{9}{|c|}{ Ukraine } & \multicolumn{3}{c|}{ EU countries } \\
\cline { 2 - 9 } & $\mathbf{W}$ & $\mathbf{V}$ & $\mathbf{Z}$ & Prob>z & $\mathbf{W}$ & $\mathbf{V}$ & $\mathbf{Z}$ & Prob >z \\
\hline Var1 & 0.964 & 0.472 & -1.048 & 0.853 & 0.945 & 0.463 & -1.027 & 0.836 \\
\hline Var 2 & 0.944 & 0.781 & -0.385 & 0.650 & 0.916 & 0.758 & -0.373 & 0.631 \\
\hline Var 3 & 0.794 & 2.868 & 1.964 & 0.025 & 0.842 & 3.040 & 2.082 & 0.066 \\
\hline Var 4 & 0.870 & 1.817 & 1.040 & 0.149 & 0.904 & 1.890 & 1.082 & 0.155 \\
\hline Var 5 & 0.934 & 0.917 & -0.137 & 0.555 & 0.990 & 0.972 & -0.145 & 0.588 \\
\hline Var 6 & 0.878 & 1.698 & 0.913 & 0.181 & 0.896 & 1.732 & 0.931 & 0.184 \\
\hline Var 7 & 0.926 & 1.026 & 0.041 & 0.484 & 0.917 & 1.016 & 0.041 & 0.479 \\
\hline Var8 & 0.863 & 1.908 & 1.132 & 0.129 & 0.846 & 1.870 & 1.109 & 0.126 \\
\hline Var 9 & 0.799 & 2.794 & 1.907 & 0.028 & 0.965 & 2.710 & 1.850 & 0.027 \\
\hline Var 10 & 0.955 & 0.629 & -0.707 & 0.760 & 0.984 & 0.648 & -0.728 & 0.783 \\
\hline Var 11 & 0.923 & 1.073 & 0.114 & 0.454 & 0.941 & 1.094 & 0.116 & 0.464 \\
\hline Var 12 & 0.908 & 1.284 & 0.415 & 0.339 & 0.944 & 1.335 & 0.432 & 0.353 \\
\hline Var 13 & 0.953 & 0.657 & -0.644 & 0.740 & 0.972 & 0.670 & -0.657 & 0.755 \\
\hline Var 14 & 0.836 & 2.278 & 1.481 & 0.069 & 0.920 & 2.506 & 1.629 & 0.076 \\
\hline Var 15 & 0.906 & 1.307 & 0.446 & 0.328 & 0.933 & 1.346 & 0.459 & 0.338 \\
\hline Var 16 & 0.975 & 0.344 & -1.523 & 0.936 & 0.936 & 0.330 & -1.462 & 0.899 \\
\hline Var 17 & 0.989 & 0.153 & -2.478 & 0.993 & 0.930 & 0.144 & -2.329 & 0.934 \\
\hline Var18 & 0.919 & 1.129 & 0.198 & 0.422 & 0.970 & 1.192 & 0.209 & 0.445 \\
\hline Var 19 & 0.871 & 1.804 & 1.026 & 0.152 & 0.962 & 1.993 & 1.134 & 0.168 \\
\hline Var 20 & 0.965 & 0.485 & -1.069 & 0.858 & 0.936 & 0.470 & -1.037 & 0.832 \\
\hline Var 21 & 0.746 & 3.535 & 2.436 & 0.007 & 0.836 & 3.959 & 2.728 & 0.008 \\
\hline Var 22 & 0.997 & 0.040 & -3.817 & 1.000 & 0.947 & 0.038 & -3.626 & 0.950 \\
\hline Var 23 & 0.834 & 2.307 & 1.507 & 0.066 & 0.854 & 2.362 & 1.543 & 0.068 \\
\hline Var 24 & 0.901 & 1.376 & 0.535 & 0.296 & 0.922 & 1.408 & 0.547 & 0.303 \\
\hline Source & & & & & & \\
\hline
\end{tabular}

Source: own calculations in Stata 12. 
In order to reveal the link between variables which are not subordinated to the normal distribution law, we calculate the Spearman's correlation coefficient. The results of calculations for indicators are shown in Table 3.

Table 3. Partial correlation coefficients between demand on the investment market and factors of its formation depending on the lags between indicators

\begin{tabular}{|c|c|c|c|c|c|c|c|c|}
\hline \multirow{3}{*}{ Index } & \multicolumn{8}{|c|}{ Capital investment } \\
\hline & \multicolumn{4}{|c|}{ Ukraine } & \multicolumn{4}{|c|}{ EU countries } \\
\hline & $\begin{array}{l}\text { lag } 0 \\
\text { years }\end{array}$ & $\begin{array}{l}\text { lag } 1 \\
\text { year }\end{array}$ & $\begin{array}{l}\text { lag } 2 \\
\text { years }\end{array}$ & $\begin{array}{l}\text { lag } 3 \\
\text { years }\end{array}$ & $\begin{array}{l}\text { lag } 0 \\
\text { years }\end{array}$ & $\begin{array}{l}\text { lag } 1 \\
\text { year }\end{array}$ & $\begin{array}{l}\text { lag } 2 \\
\text { years }\end{array}$ & $\begin{array}{l}\text { lag } 3 \\
\text { years }\end{array}$ \\
\hline var1 & 0.13 & 0.90 & 0.83 & 0.81 & 0.65 & 0.84 & 0.98 & 0.94 \\
\hline Var 2 & 0.94 & 0.69 & 0.55 & 0.49 & 0.92 & 0.79 & 0.69 & 0.78 \\
\hline Var 3 & -0.42 & -0.44 & -0.57 & -0.89 & -0.83 & -0.87 & -0.67 & -0.91 \\
\hline Var 4 & 0.76 & 0.53 & 0.27 & 0.02 & 0.95 & 0.61 & 0.55 & 0.40 \\
\hline Var 5 & 0.83 & 0.73 & 0.28 & 0.16 & 0.85 & 0.82 & 0.72 & 0.64 \\
\hline Var 6 & 0.59 & - & - & - & 0.44 & 0.32 & 0.21 & 0.01 \\
\hline Var 7 & 0.21 & -0.53 & -0.87 & -0.92 & -0.36 & -0.46 & -0.78 & -0.95 \\
\hline Var8 & 0.48 & 0.38 & 0.40 & 0.62 & 0.33 & 0.26 & 0.01 & 0.32 \\
\hline Var 9 & 0.32 & 0.19 & -0.23 & -0.15 & 0.37 & 0.25 & 0.21 & 0.01 \\
\hline Var 10 & 0.17 & 0.29 & 0.44 & 0.53 & 0.25 & 0.66 & 0.79 & 0.98 \\
\hline Var 11 & -0.32 & -0.02 & 0.28 & 0.60 & 0.01 & 0.46 & 0.79 & 0.85 \\
\hline Var 12 & -0.28 & -0.63 & -0.78 & -0.94 & -0.37 & -0.46 & -0.79 & -0.95 \\
\hline Var 13 & 0.55 & 0.29 & 0.17 & 0.19 & 0.21 & -0.01 & -0.37 & -0.15 \\
\hline Var 14 & -0.67 & -0.60 & -0.47 & -0.49 & 0.37 & 0.55 & 0.86 & 0.90 \\
\hline Var 15 & -0.20 & -0.64 & -0.90 & -0.95 & 0.55 & 0.32 & 0.30 & 0.11 \\
\hline Var 16 & -0.18 & -0.46 & -0.64 & -0.82 & -0.37 & -0.55 & -0.70 & -0.68 \\
\hline Var 17 & -0.55 & -0.53 & -0.74 & -0.89 & -0.66 & -0.75 & -0.87 & -0.93 \\
\hline Var18 & 0.72 & 0.67 & 0.18 & 0.07 & 0.87 & 0.97 & 0.33 & 0.21 \\
\hline Var 19 & -0.09 & 0.81 & 0.94 & 0.96 & 0.37 & 0.65 & 0.90 & 1.00 \\
\hline Var 20 & 0.86 & 0.57 & - & - & 0.95 & 0.85 & 0.33 & 0.21 \\
\hline Var 21 & 0.01 & 0.36 & 0.87 & 0.87 & 0.05 & 0.30 & 0.33 & 0.25 \\
\hline Var 22 & -0.31 & -0.62 & -0.84 & - & -0.65 & -0.85 & -0.87 & -0.87 \\
\hline Var 23 & -0.10 & -0.22 & -0.21 & -0.82 & -0.50 & -0.66 & -0.84 & -0.94 \\
\hline Var 24 & -0.77 & -0.15 & - & - & -0.45 & -0.21 & 0.00 & - \\
\hline
\end{tabular}

Source: own calculations in Stata 12.

Based on the analysis of the data from Table 3, it is necessary to point out that within 24 indicators of the impact on the demand level on the investment market, the following groups are defined: indicators, the time period which coincides with the time period of the capital investment, indicators, with lag of 1, 2 and 3 years. The calculations indicate the absence of the essential link between the analysed indicators for time lag 4 years and more. Therefore, we will represent the results of the study with time lag 0-3 years.

Taking into account the results of the third stage we will write the empiric regression equation of the capital investment dependence on the key factors of their formation on the investment market: 


$$
\begin{aligned}
D(t)_{\mathrm{UKR}}=d_{0} \times u_{1}^{d_{1}} & \left(t-l_{1}\right) \times u_{2}^{d_{2}}\left(t-l_{2}\right) \times u_{3}^{d_{3}}\left(t-l_{3}\right) \times u_{4}^{d_{4}}\left(t-l_{4}\right) \times u_{5}^{d_{5}}\left(t-l_{5}\right) \times u_{7}^{d_{7}}\left(t-l_{7}\right) \\
& \left.\times u_{12}^{d_{12}}\left(t-l_{12}\right) \times u_{15}^{d_{15}}\left(t-l_{15}\right) \times u_{16}^{d_{16}}\left(t-l_{16}\right) \times u_{17}^{d_{17}}\left(t-l_{17}\right) \times u_{18}^{d_{18}}\left(t-l_{18}\right)\right) \\
& \left.\left.\left.\left.\times u_{19}^{d_{19}}\left(t-l_{19}\right)\right) \times u_{20}^{d_{20}}\left(t-l_{20}\right)\right) \times u_{21}^{d_{21}}\left(t-l_{21}\right)\right) \times u_{22}^{d_{22}}\left(t-l_{22}\right)\right) \times u_{23}^{d_{23}}(t \\
& \left.\left.\left.-l_{23}\right)\right) \times u_{24}^{d_{24}}\left(t-l_{24}\right)\right)
\end{aligned}
$$

Since the multiplicative function is chosen to construct the models, the precondition to implement possibilities of the statistic analysis is to convert the equation to the linear form, i.e. its linearisation through taking the logarithm of the right and left parts, which in terms of the demand analysis is shown in the following way:

$$
\begin{gathered}
D(t)_{U K R}=\ln d_{0}+d_{1} \times \ln u_{1}\left(t-l_{1}\right)+d_{2} \times \ln u_{2}\left(t-l_{2}\right)+d_{3} \times \ln u_{3}\left(t-l_{3}\right)+d_{4} \times \ln u_{4}\left(t-l_{4}\right)+ \\
d_{5} \times \ln u_{5}\left(t-l_{5}\right)+d_{7} \times \ln u_{7}\left(t-l_{7}\right)+d_{12} \times \ln u_{12}\left(t-l_{12}\right)+d_{15} \times \ln u_{15}\left(t-l_{15}\right)+d_{16} \times \\
\ln u_{16}\left(t-l_{16}\right)+d_{17} \times \ln u_{17}\left(t-l_{17}\right)+d_{18} \times \ln u_{18}\left(t-l_{18}\right)+d_{19} \times \ln u_{19}\left(t-l_{19}\right)+d_{20} \times \\
\ln u_{20}\left(t-l_{20}\right)+d_{21} \times \ln u_{21}\left(t-l_{21}\right)+d_{22} \times \ln u_{22}\left(t-l_{22}\right)+d_{23} \times \ln u_{23}\left(t-l_{23}\right)+d_{17} \times \\
\ln u_{24}\left(t-l_{24}\right)
\end{gathered}
$$

Transformation of the obtained data to the linearity on the investment market requires a transformation of the informational base (Table 3 ) to the form of Table 4.

In order to construct the econometric model, those drivers of the shadow economy are used for which the close correlation is observed during the three years of the study ( 0.7 and more). For example, since the EU countries do not have a strong link between the capital investment volume and the level of the deposit outflow, the number of the solvent banks, the level of import and export, the foregone earnings for export of goods and services, these indicators are not taken into account in the construction of the model.

Table 4. Informational provision of the econometric model regarding the dependence of the demand level on the macroeconomic factors of the proper indicator formation on the investment market

\begin{tabular}{|c|c|c|c|c|c|c|c|c|c|}
\hline \multicolumn{2}{|c|}{ Factor } & $\mathbf{2 0 1 0}$ & $\mathbf{2 0 1 1}$ & $\mathbf{2 0 1 2}$ & $\mathbf{2 0 1 3}$ & $\mathbf{2 0 1 4}$ & $\mathbf{2 0 1 5}$ & $\mathbf{2 0 1 6}$ & $\mathbf{2 0 1 7}$ \\
\hline \multirow{2}{*}{$\operatorname{Ln}(\mathrm{d})$} & UKR & 12.15 & 12.47 & 12.59 & 12.50 & 12.30 & 12.52 & 12.79 & 12.93 \\
\cline { 2 - 11 } & EU & 19.28 & 19.60 & 19.72 & 19.63 & 19.43 & 19.65 & 19.93 & 20.06 \\
\hline \multirow{2}{*}{$\operatorname{Ln}\left(\mathrm{u}_{1}\right)$} & UKR & 2.45 & 2.52 & 2.10 & 1.97 & 2.75 & 3.23 & 2.85 & 2.77 \\
\cline { 2 - 11 } & EU & 2.82 & 2.89 & 2.47 & 2.34 & 3.12 & 3.60 & 3.23 & 3.14 \\
\hline \multirow{2}{*}{$\operatorname{Ln}\left(\mathrm{u}_{2}\right)$} & UKR & 2.31 & 2.22 & 2.56 & 2.65 & 2.60 & 2.57 & 2.21 & 2.35 \\
\cline { 2 - 11 } & EU & 4.17 & 3.47 & 1.95 & 2.08 & 2.08 & 2.20 & 2.20 & 2.20 \\
\hline \multirow{2}{*}{$\operatorname{Ln}\left(\mathrm{u}_{3}\right)$} & UKR & 4.99 & 4.91 & 4.91 & 3.33 & 3.33 & 1.61 & 1.61 & 1.61 \\
\cline { 2 - 11 } & EU & 12.12 & 12.04 & 12.04 & 10.47 & 10.47 & 8.74 & 8.74 & 8.74 \\
\hline \multirow{2}{*}{$\operatorname{Ln}\left(\mathrm{u}_{4}\right)$} & UKR & 10.88 & 11.03 & 11.16 & 11.27 & 11.30 & 11.50 & 11.65 & 11.87 \\
\cline { 2 - 11 } & EU & 18.01 & 18.16 & 18.30 & 18.40 & 18.43 & 18.64 & 18.79 & 19.01 \\
\hline \multirow{2}{*}{$\operatorname{Ln}\left(\mathrm{u}_{5}\right)$} & UKR & 1.32 & 1.95 & 1.74 & 1.45 & 1.01 & 0.89 & 0.94 & 1.01 \\
\cline { 2 - 11 } & EU & 1.65 & 2.05 & 1.86 & 1.63 & 1.16 & 1.10 & 1.13 & 1.22 \\
\hline \multirow{2}{*}{$\operatorname{Ln}\left(\mathrm{u}_{7}\right)$} & UKR & 4.70 & 4.69 & 4.71 & 4.67 & 4.46 & 4.50 & 4.67 & 4.78 \\
\cline { 2 - 10 } & EU & 4.72 & 4.70 & 4.72 & 4.68 & 4.47 & 4.51 & 4.68 & 4.79 \\
\hline $\operatorname{Ln}\left(\mathrm{u}_{10}\right)$ & EU & 1.90 & 1.65 & 2.09 & 1.91 & 2.01 & 2.11 & 2.00 & 1.78 \\
\hline $\operatorname{Ln}\left(\mathrm{u}_{11}\right)$ & EU & 12.45 & 12.40 & 12.35 & 12.27 & 12.32 & 12.96 & 13.25 & 12.41 \\
\hline \multirow{2}{*}{$\operatorname{Ln}\left(\mathrm{u}_{12}\right)$} & UKR & 10.85 & 11.13 & 11.14 & 11.06 & 10.89 & 10.55 & 10.50 & 10.68 \\
\cline { 2 - 10 } & EU & 17.98 & 18.27 & 18.27 & 18.19 & 18.03 & 17.68 & 17.64 & 17.81 \\
\hline $\operatorname{Ln}\left(\mathrm{u}_{14}\right)$ & EU & 18.95 & 18.93 & 18.94 & 16.61 & 16.39 & 18.70 & 17.95 & 18.51 \\
\hline $\operatorname{Ln}\left(\mathrm{u}_{15}\right)$ & UKR & 11.01 & 11.32 & 11.35 & 11.25 & 10.90 & 10.53 & 10.58 & 10.81 \\
\hline $\operatorname{Ln}\left(\mathrm{u}_{16}\right)$ & UKR & 3.19 & 2.89 & 2.80 & 2.84 & -0.22 & 1.82 & 2.37 & 2.59 \\
\hline
\end{tabular}




\begin{tabular}{|c|c|c|c|c|c|c|c|c|c|}
\hline \multicolumn{2}{|c|}{ Factor } & $\mathbf{2 0 1 0}$ & $\mathbf{2 0 1 1}$ & $\mathbf{2 0 1 2}$ & $\mathbf{2 0 1 3}$ & $\mathbf{2 0 1 4}$ & $\mathbf{2 0 1 5}$ & $\mathbf{2 0 1 6}$ & $\mathbf{2 0 1 7}$ \\
\hline \multirow{2}{*}{$\operatorname{Ln}\left(\mathrm{u}_{17}\right)$} & UKR & 4.05 & 4.02 & 4.04 & 4.01 & 4.00 & 3.96 & 3.96 & 3.96 \\
\cline { 2 - 10 } & EU & 3.89 & 3.86 & 3.89 & 3.86 & 3.84 & 3.81 & 3.80 & 3.80 \\
\hline \multirow{2}{*}{$\operatorname{Ln}\left(\mathrm{u}_{18}\right)$} & UKR & 4.05 & 4.15 & 4.14 & 4.17 & 4.18 & 4.29 & 4.29 & 4.24 \\
\cline { 2 - 10 } & EU & 4.48 & 4.58 & 4.57 & 4.54 & 4.55 & 4.57 & 4.58 & 4.59 \\
\hline \multirow{2}{*}{$\operatorname{Ln}\left(\mathrm{u}_{19}\right)$} & UKR & 4.69 & 4.65 & 4.60 & 4.61 & 4.83 & 4.96 & 4.72 & 4.73 \\
\cline { 2 - 10 } & EU & 4.56 & 4.52 & 4.47 & 4.48 & 4.69 & 4.83 & 4.59 & 4.60 \\
\hline \multirow{2}{*}{$\operatorname{Ln}\left(\mathrm{u}_{20}\right)$} & UKR & 3.18 & 3.26 & 3.26 & 3.22 & 3.26 & 3.30 & 3.37 & 3.40 \\
\cline { 2 - 10 } & EU & 2.89 & 2.98 & 3.02 & 2.98 & 3.02 & 3.05 & 3.13 & 3.16 \\
\hline $\operatorname{Ln}\left(\mathrm{u}_{21}\right)$ & UKR & 5.20 & 5.17 & 5.17 & 5.17 & 5.19 & 5.09 & 4.76 & 4.53 \\
\hline \multirow{2}{*}{$\operatorname{Ln}\left(\mathrm{u}_{22}\right)$} & UKR & 1.01 & 1.02 & 1.02 & 0.97 & 0.85 & 0.86 & 0.84 & 0.82 \\
\cline { 2 - 10 } & EU & 2.53 & 2.54 & 2.54 & 2.49 & 2.38 & 2.38 & 2.36 & 2.34 \\
\hline \multirow{2}{*}{$\operatorname{Ln}\left(\mathrm{u}_{23}\right)$} & UKR & 7.21 & 6.89 & 7.23 & 6.49 & 6.36 & 6.36 & 6.66 & 7.09 \\
\cline { 2 - 10 } & EU & 12.04 & 11.72 & 12.05 & 11.32 & 11.19 & 11.19 & 11.49 & 11.92 \\
\hline $\operatorname{Ln}\left(\mathrm{u}_{24}\right)$ & UKR & 2.83 & 4.53 & 4.74 & 3.71 & -9.21 & 3.95 & 4.58 & 4.72 \\
\hline
\end{tabular}

Source: own calculations in Stata 12.

The obtained results of the performed statistic analysis regarding the dependence of the capital investment level on the significant factors of the demand formation on the investment market are demonstrated in Table 5.

Table 5. Results of the statistic analysis regarding the dependence of the capital investment level on the significant factors for the demand formation at the investment market

\begin{tabular}{|c|c|c|c|c|c|c|}
\hline & & Coefficient & Standard & t-statistics & Down 95\% & Upper 95\% \\
\hline Y-inter- & Ukr & 0.12 & 0.04 & 1.915 & 0.42 & 0.42 \\
\hline section & EU & 0.21 & 0.03 & 2.011 & 0.67 & 0.37 \\
\hline & Ukr & 0.36 & 0.09 & 0.875 & 0.36 & 0.36 \\
\hline $\mathrm{u}_{1}$ & EU & 0.42 & 0.04 & 0.831 & 0.42 & 0.42 \\
\hline th & Ukr & 0.44 & 0.07 & 2.419 & 0.44 & 0.44 \\
\hline $\mathrm{u}_{2}$ & EU & 0.38 & 0.06 & 2.540 & 0.38 & 0.38 \\
\hline & Ukr & 0.13 & 0.11 & 0.086 & 0.13 & 0.13 \\
\hline$u_{3}$ & EU & 0.11 & 0.09 & 0.099 & 0.11 & 0.11 \\
\hline 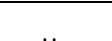 & Ukr & 0.39 & 0.08 & 1.173 & 0.39 & 0.39 \\
\hline $\mathrm{u}_{4}$ & EU & 0.18 & 0.02 & 1.232 & 0.18 & 0.18 \\
\hline & Ukr & 0.41 & 0.10 & 1.587 & 0.41 & 0.41 \\
\hline $\mathrm{u}_{5}$ & EU & 0.24 & 0.07 & 1.666 & 0.24 & 0.24 \\
\hline 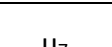 & Ukr & 0.46 & 0.04 & 4.234 & 0.46 & 0.46 \\
\hline$u_{7}$ & $E U$ & 0.54 & 0.05 & 3.175 & 0.54 & 0.54 \\
\hline $\mathrm{u}_{10}$ & EU & 0.38 & 0.06 & 1.702 & 0.38 & 0.38 \\
\hline $\mathrm{u}_{11}$ & EU & 0.25 & 0.12 & 1.516 & 0.25 & 0.25 \\
\hline & Ukr & 0.41 & 0.09 & 1.621 & 0.41 & 0.41 \\
\hline $\mathrm{u}_{12}$ & EU & 0.17 & 0.04 & 0.197 & 0.17 & 0.17 \\
\hline $\mathrm{u}_{14}$ & EU & 0.34 & 0.03 & 11.327 & 0.34 & 0.34 \\
\hline $\mathrm{u}_{15}$ & Ukr & 0.39 & 0.10 & 1.212 & 0.39 & 0.39 \\
\hline $\mathrm{u}_{16}$ & Ukr & 0.19 & 0.11 & 0.178 & 0.19 & 0.19 \\
\hline & Ukr & 0.49 & 0.01 & 13.020 & 0.49 & 0.49 \\
\hline $\mathrm{u}_{17}$ & EU & 0.52 & 0.04 & 4.489 & 0.52 & 0.52 \\
\hline
\end{tabular}




\begin{tabular}{|c|c|c|c|c|c|c|}
\hline \multicolumn{2}{|c|}{ Factor } & Coefficient & $\begin{array}{c}\text { Standard } \\
\text { error }\end{array}$ & t-statistics & Down 95\% & Upper 95\% \\
\hline \multirow{2}{*}{$\mathrm{u}_{18}$} & $\mathrm{Ukr}$ & 0.47 & 0.03 & 5.682 & 0.47 & 0.47 \\
\cline { 2 - 7 } & $\mathrm{EU}$ & 0.44 & 0.06 & 5.009 & 0.44 & 0.44 \\
\hline \multirow{2}{*}{$\mathrm{U}_{19}$} & $\mathrm{Ukr}$ & 0.46 & 0.05 & 3.772 & 0.46 & 0.46 \\
\cline { 2 - 7 } & $\mathrm{EU}$ & 0.5 & 0.01 & 2.226 & 0.5 & 0.50 \\
\hline \multirow{2}{*}{$\mathrm{U}_{20}$} & $\mathrm{Ukr}$ & 0.47 & 0.03 & 6.422 & 0.47 & 0.47 \\
\cline { 2 - 7 } & $\mathrm{EU}$ & 0.36 & 0.01 & 3.923 & 0.36 & 0.36 \\
\hline $\mathrm{U}_{21}$ & $\mathrm{Ukr}$ & 0.41 & 0.09 & 1.649 & 0.41 & 0.41 \\
\hline \multirow{2}{*}{$\mathrm{U}_{22}$} & $\mathrm{Ukr}$ & 0.47 & 0.03 & 5.301 & 0.47 & 0.47 \\
\cline { 2 - 7 } & $\mathrm{EU}$ & 0.42 & 0.05 & 1.152 & 0.42 & 0.42 \\
\hline \multirow{2}{*}{$\mathrm{U}_{23}$} & $\mathrm{Ukr}$ & 0.37 & 0.04 & 1.019 & 0.37 & 0.37 \\
\cline { 2 - 7 } & $\mathrm{EU}$ & 0.09 & 0.02 & 0.004 & 0.09 & 0.09 \\
\hline $\mathrm{U}_{24}$ & $\mathrm{Ukr}$ & 0.02 & 0.09 & 0.004 & 0.02 & 0.02 \\
\hline
\end{tabular}

Source: own calculations in Stata 12.

Based on column 2 in Table 5, we receive a concrete form of the dependence of the capital investment level on the investment market through the following mathematical ratio:

$$
\begin{gathered}
D(t)_{U K R}=\mathrm{e}^{0,12} \times u_{1}^{0,36}(t-1) \times u_{2}^{0,44}(t) \times u_{3}^{0,13}(t-3) \times u_{4}^{0,39}(t) \times u_{5}^{0,41}(t) \times u_{7}^{0,46}(t-2) \times \\
u_{12}^{0,41}(t-2) \times u_{15}^{0,39}(t-2) \times u_{16}^{0,19}(t-3) \times u_{17}^{0,49}(t-2) \times u_{18}^{0,47}(t) \times u_{19}^{0,46}(t-1) \times u_{20}^{0,47}(t) \times \\
u_{21}^{0,41}(t-2) \times u_{22}^{0,47}(t-2) \times u_{23}^{0,37}(t-3) \times u_{24}^{0,02}(t) \\
D(t)_{E U}=\mathrm{e}^{0,21} \times u_{1}^{0,42}(t-1) \times u_{2}^{0,38}(t) \times u_{3}^{0,11}(t) \times u_{4}^{0,18}(t) \times u_{5}^{0,24}(t) \times u_{7}^{0,54}(t-2) \times \\
u_{10}^{0,38}(t-2) \times u_{11}^{0,25}(t-2) \times u_{12}^{0,17}(t-2) \times u_{14}^{0,34}(t-2) \times u_{17}^{0,52}(t-1) \times u_{18}^{0,39}(t) \times u_{18}^{0,44}(t) \times \\
u_{19}^{0,50}(t-2) \times u_{20}^{0,36}(t) \times u_{22}^{0,42}(t-1) \times u_{23}^{0,09}(t-2)
\end{gathered}
$$

\section{CONCLUSIONS}

In this study, the factorial indicators which have the highest, medium impact and those that practically do not affect the result indicator are identified. The results of the analysis carried out enable to define factors which do not influence the investment activity level in the EU countries and in Ukraine: the official level of unemployment, the official exchange rate of the national currency in relation to the Euro, the interest rate for deposits, the volume of public debt. At the same time, some drivers of the shadow economy, the impact of which differs depending on a country's economic development, are identified. Interest rate for credits, the level of the labour migration do not influence the capital investment volume in Ukraine, whereas for the EU countries the list of such factors is wider, they include the level of import and export, the level of the deposit outflow, the number of solvent banks, the foregone earnings for export of goods and services.

The defined factors of the shadow economy which influence the capital investment volume in the country can be the base for further scientific studies to find priority measures to increase a country's investment attractiveness. The results of the performed modelling can be tools to analyse the development of the native investment market by all entities. The state and economic entities, which may be either investors or consumers of the investment resources at once, have the ability operatively to make adjustments to their own strategy, oriented to increase the countries' economic growth and to satisfy 
public needs in the case of the state regulation, and in the case of other participants from the investment market - to maximise the profit.

Despite the current limitation of the sample size through the analysis of only Ukraine as a country with an average level of development, which tries to be a member of the EU, that does not let to make general and fundamental conclusions, we prove that some drivers of the shadow economy influence the capital investment volumes of some countries in various ways. However, the reasons for these differences within this research are not analysed. Secondly, we do not consider the fact that for some factors an average correlation can be increasingly caused by the similarity of tendencies regarding the changes in these indicators, but not by the close relationship between them. Thirdly, the sample size is due to the limitation of data for some countries in the world that does not enable to take most factors into account.

The goal of further research may be to define the tightness and nature of the relationship between the analysed factors and to construct a model which considers the synergy effect from the complex influence of the analysed factors, provides the evaluation of the significance level regarding the shadow economy drivers together with other factors of the impact on the capital investment volume in a country.

\section{REFERENCES}

Abed, G.T., \& Davoodi, H.R. (2002). Corruption, Structural Reforms, and Economic Performance. Governance, Corruption \& Economic Performance, International Monetary Fund, Washington D.C., 489-537.

Abror, Q.A. (2015). Effects of shadow economy on foreign direct investment. Proceeding - Kuala Lumpur International Business, Economics and Law Conference, 6(3), Hotel Putra, Kuala Lumpur, Malaysia.

Addison, T., \& Heshmati, A. (2003). The New Global Determinants of FDI Flows to Developing Countries. World Institute For Development Economics Research WIDER, Discussion Paper No. 2003/45.

Al-Sadig, A. (2007). The effects of corruption on FDI inflows. The Cato Journal, 29, 267.

Asiedu, E. (2006). Foreign Direct Investment in Africa: The Role of Natural Resources, Market Size, Government Policy, Institutions and Political Instability. World Economy, 29, 63-77. https://doi.org/10.1111/j.1467-9701.2006.00758.x

Bilan, Y., Korauš, A., Simionescu M., \& Schönfeld, J. (2017). The impact of monetary variables on the economic growth and sustainable development: Case of selected countries. Journal of Security and Sustainability Issues, 6(3), 383-390. http://jssidoi.org/jssi/papers/papers/view/216

Bilan, Y., Mishchuk, H., Samoliuk, N., \& Streimikiene, D. (2018). Income Inequality and its Consequences within the Framework of Social Justice. Problemy Ekorozwoju - Problems of Sustainable Development, 13(2), 131-138.

Bilan, Yu., Moroz, S., Nagyova, L., Horska, E., \& Polakova, Z. (2017). The current state and prospects of trade relations between Ukraine and the European Union: the Visegrad vector. Economic Annals-XXI, 163(1-2(1)), 14-21.

Bobenič Hintošová, A., Bruothová, M., Kubíková, Z., \& Ručinský R. (2018). Determinants of foreign direct investment inflows: A case of the Visegrad countries. Journal of International Studies, 11(2), 222-235. http://doi.org/10.14254/2071-8330.2018/11-2/15

Cheba, K., \& Szopik-Depczyńska, K. (2017). Multidimensional comparative analysis of the competitive capacity of the European Union countries and geographical regions. Oeconomia Copernicana, 8(4), 487-504. https://doi.org/10.24136/oc.v8i4.30 
Cichocki, S., \& Tyrowicz, J. (2010). Shadow employment in post-transition - Is informal employment a matter of choice or no choice in Poland?. The Journal of Socio-Economics, 39(4), 527-535.

Cleeve, E. (2008). How Effective Are Fiscal Incentives to Attract FDI to Sub-Saharan Africa?. The Journal of Developing Areas, 42, 135-153.

Damoska Sekuloska, J. (2018). Causality between foreign direct investment in the automotive sector and export performance of Macedonian economy. Equilibrium. Quarterly Journal of Economics and Economic Policy, 13(3), 427-443. https://doi.org/10.24136/eq.2018.021

Demirhan, E., \& Masca, M. (2008). Determinants of Foreign Direct Investment Flows. Prague Economic Papers, 4, 356-369. https://doi.org/10.18267/j.pep.337

Djalilov, K., Lyeonov, S., \& Buriak, A. (2015). Comparative studies of risk, concentration and efficiency in transition economies. Risk Governance \& Control: Financial Markets \& Institutions, 5(4(1)), 177-186.

Do, M.H., \& Park, S.C. (2018). New Rural Development and hierarchical governance in Vietnam: Impacts of government support on rural households' income using a hierarchical linear modelling. Agris On-line Papers in Economics and Informatics 10(4), 3-15.

Egger, P., \& Winner, H. (2005). Evidence on Corruption as an Incentive for Foreign Direct Investment. European Journal of Political Economy, 21(4), 932-952.

Enste, D.H. (2015). The shadow economy in industrial countries. IZA World of Labour 2015, 127, 1-10. https://doi.org/10.15185/izawol.127

Fernandes, A.J.L. (2018). Transnational banks' influence on the development of the economy and the financial sector of developing countries (on the example of Poland, Brazil, Turkey). Marketing and Management of Innovations, 3, 253-259. http://doi.org/10.21272/mmi.2018.3-22

Formankova, S., Trenz, O., Faldik, O., Kolomaznik, J., \& Vanek, P. (2018). The future of investingsustainable and responsible investing. Marketing and Management of Innovations, 2, 94-102. http://doi.org/10.21272/mmi.2018.2-08

Greco, F. (2018). Resilience: Transform adverse events into an opportunity for growth and economic sustainability through the adjustment of emotions. Business Ethics and Leadership, 2(1), 44-52. https://doi.org/10.21272/bel.2(1).44-52.2018

Hubert, P.J., \& Phanindra, V.W. (2004). Determinants of foreign direct investment: empirical evidence from EU accession candidates. Applied Economics, 36, 505-509. https://doi.org/10.1080/00036840410001682214

Ipatov, B.G., McClelland, B., Williamson, P., Khanfar, N., \& Cavico, F.J. (2018). An Analysis of the Relationship between Regulatory Control and Corruption based on Product and Market Regulation and Corruption Perceptions Indices. Business Ethics and Leadership, 2(3), 6-20. https://doi.org/10.21272/bel.2(3).6-20.2018

Ipatov, M., \& Grebeniuk, N. (2018). Assessing the level of adaptation of employees to the transformation processes in the company. Business Ethics and Leadership, 2(1), 106-115. https://doi.org/10.21272/bel.2(1).106-115.2018

Kostyuchenko, N., Starinskyi, M., Tiutiunyk, S., \& Kobushko, la. (2018). Methodical Approach to the Assessment of Risks Connected With the Legalization of the Proceeds of Crime. Montenegrin Journal of Economics, 14(4), 021-041.

Krumplyte, J. (2008). Šešelines ekonomikos samprata ir priežasciu analize. Ekonomika ir Vadyba: Aktualijos ir Perspektyvos, 4(13), 238-250.

Lambsdorff, J. Graf, \& Cornelius, P. (2000). Corruption, Foreign Investment and Growth, The Africa Competitiveness Report 2000/2001. Harvard University: Oxford University Press, (pp. 70-78).

Leonov, S.V., \& Isaieva, O.V. (2014). Determinants of government bond spread in Ukraine and new EU members, Actual Problems of the Economics, 5, 416-425. 
Lyeonov, S.V., Vasylieva, T.A., \& Lyulyov, O.V. (2018). Macroeconomic stability evaluation in countries of lower-middle income economies. Scientific Bulletin of National Mining University, 1, 138-146. https://doi.org/10.29202/nvngu/2018-1/4

Melnyk, L., Sineviciene, L., Lyulyov, O., Pimonenko, T., \& Dehtyarova, I. (2018). Fiscal decentralization and macroeconomic stability: the experience of Ukraine's economy. Problems and Perspectives in Management, 16(1), 105-114. https://doi.org/10.21511/ppm.16(1).2018.10

Morrissey, O., \& Udomkerdmongkol, M. (2012). Governance, Private Investment and Foreign Direct Investment in Developing Countries. World Development, 40, 437-445.

Nazarczuk, J.M., \& Krajewska, A. (2018). Local determinants of foreign direct investment in Poland: the role of relative distance. Equilibrium. Quarterly Journal of Economics and Economic Policy, 13(1), 73-88. https://doi.org/10.24136/eq.2018.004

Nunes, P., Serrasqueiro, Z., \& Matos, A. (2017). Determinants of investment in fixed assets and in intangible assets for high-tech firms. Journal of International Studies, 10(1), 173-179. https://doi.org/10.14254/2071-8330.2017/10-1/12

Omidi, M., Min, Q., \& Omidi, M. (2017). Combined Effect of Economic Variables on Fraud, a Survey of Developing Countries. Economics and Sociology, 10(2), 267-278. https://doi.org/10.14254/2071-789X.2017/10-2/20

Rahimi, F.A.F. (2016). The impact of international forces withdrawal on investment in Herat, Afghanistan. Journal of International Studies, 9(1), 44-55. https://doi.org/10.14254/2071-8330.2016/9-1/3

Rausser, G., Strielkowski, W., Bilan, Y., \& Tsevukh, Y. (2018). Migrant remittances and their impact on the economic development of the Baltic States. Geographica Pannonica, 22(3), 165-175.

Riedl, A. (2009). Location factors of FDI and the growing services economy. Economics of Transition, 18(4), 741-761. https://doi.org/10.1111/j.1468-0351.2010.00391.x

Schneider, F. (2007). Shadow economies and corruption all over the world: New estimates for 145 countries. Open-Assessment E-Journal, 1, 1-66.

Skare, M., \& Porada-Rochoń, M. (2019). Financial and economic development link in transitional economies: a spectral Granger causality analysis 1991-2017. Oeconomia Copernicana, 10(1), 7-35. https://doi.org/10.24136/oc.2019.001

Smarzynska, B.K., \& Wei, S. (2000). Corruption and the Composition of Foreign Direct Investment: FirmLevel Evidence. World Bank Discussion Paper Series no. 2360. Washington, DC: World Bank.

Sookram, S., Watson, P.K., \& Schneider, F. (2009). Characteristics of households in the informal sector of an emerging economy. Applied Economics, 41(27), 3545-3559. https://doi.org/10.1080/00036840701493733

Špička, J. (2018). Dynamic effects of public investment support in the food and beverage industries. Agris On-line Papers in Economics and Informatics, 10(1), 91-110.

Teobaldelli, D., \& Schneider, F. (2013). The influence of direct democracy on the shadow economy. Public Choice, 157(3), 157-543.

Udomkerdmongkol, M., Görg, H., \& Morrissey, O. (2006) Foreign Direct Investment and Exchange rates: A case study of U.S. FDI in emerging countries. University of Nottingham, Discussion Papers in Economics, Discussion Paper No. 06/05.

Vasilyeva, T., Sysoyeva, L., \& Vysochyna, A. (2016). Formalization of factors that are affecting the stability of Ukraine banking system. Risk Governance \& Control: Financial Markets \& Institutions, 6(4), 7-11. https://doi.org/10.22495/rcgv6i4art1

Vasilyeva, T.A., Lunyakov, O.V., \& Leonov, S.V. (2013). Analysis of internal and external imbalances in the financial sector of Ukraine's economy. Actual Problems of the Economics, 12(150), 176-184. 
Vasylieva, T., Lyeonov, S., Lyulyov, O., \& Kyrychenko, K. (2018). Macroeconomic stability and its impact on the economic growth of the country. Montenegrin Journal of Economics, 14(1), 159170. https://doi.org/10.14254/1800-5845/2018.14-1.12

Wei, S.-J. (2000). How Taxing is Corruption on International Investors?. Review of Economics and Statistics, 82, 1-11. https://doi.org/10.1162/003465300558533

Williams, C.C., \& Nadin, S. (2012) Joining up the fight against undeclared work in Europe. Management Decision, 50(10), 1758-1771. https://doi.org/10.1108/00251741211279585

Zdziarski, M., Światowiec-Szczepańska, J., Troilo, M., \& Małys, Ł., (2017). Adventurous Foreign Direct Investment. Journal of Management and Business Administration, 25(2), 117-139.

\section{Authors}

The contribution share of authors is equal and amounted to $25 \%$ each of them.

\section{Yuriy Bilan}

Dr hab. (Rzeszow University of Technology, Poland), Professor (Rzeszow University of Technology, Poland). His research interests include economic development, investment, innovation activity, finance.

Correspondence to: Prof. Dr. Yuriy Bilan, Rzeszow University of Technology, Aleja Powstańców Warszawy 12, 35-959 Rzeszów, Poland, e-mail: y.bilan@prz.edu.pl

ORCID (1) http://orcid.org/0000-0003-0268-009X

\section{Tatiana Vasylieva}

Doctor of Economics (Ukrainian Academy of Banking, Ukraine), Professor (Ukrainian Academy of Banking, Ukraine). Her research interests include banking, investment, risk management, innovation activity, social responsibility, education.

Correspondence to: Prof. Dr Tatiana Vasylieva, Oleg Balatskyi Academic and Research Institute of Finance, Economics and Management, Sumy State University, Rimsky-Korsakov st., 2, 40001, Sumy, Ukraine, e-mail: tavasilyeve@fem.sumdu.edu.ua

ORCID (1) http://orcid.org/0000-0003-0635-7978

\section{Sergij Lyeonov}

Doctor of Economics (Ukrainian Academy of Banking, Ukraine), Professor (Ukrainian Academy of Banking, Ukraine). His research interests include banking, investment, risk management, innovation activity.

Correspondence to: Prof., Dr Sergij Lyeonov, Economic Cybernetics Department, Sumy State University, Rimsky-Korsakov st., 2, 40001, Sumy, Ukraine, e-mail: s.lieonov@uabs.sumdu.edu.ua ORCID (1) http://orcid.org/0000-0001-5639-3008

\section{Inna Tiutiunyk}

$\mathrm{PhD}$ in economics (Sumy State University, Ukraine). Her research interests include shadow economy, investment, finance, fiscal policy.

Correspondence to: PhD Inna Tiutiunyk, Finance and Entrepreneurship Department, Sumy State University, Rimsky-Korsakov st., 2, 40001, Sumy, Ukraine, e-mail: i.karpenko@finance.sumdu.edu.ua ORCID (1) http://orcid.org/0000-0001-5883-2940 


\section{Acknowledgements and Financial Disclosure}

The article was written within the project no. 0117 U003930 entitled 'Econometric modelling of the mechanism of prevention of shadow capital outflows schemes through tax and investment channels in Ukraine' financed by Ministry of Education and Science of Ukraine conducted by Sumy State University in the years 2017-2020.

The article was written within the project no. 0117 U002251 entitled 'Improvement of national anti-money laundering system in terms of increasing the financial and economic security of the state' financed by Ministry of Education and Science of Ukraine conducted by Sumy State University in the years 2017-2019.

The article came into being within the project no. 0118 U003569 entitled 'Modeling and forecasting the socio-economic-political road map of reforms in Ukraine for the transition to a sustainable growth model' financed by Ministry of Education and Science of Ukraine conducted by Sumy State University in the years 2018-2020.

\section{Copyright and License}

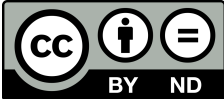

This article is published under the terms of the Creative Commons

Attribution - NoDerivs (CC BY-ND 4.0) License

http://creativecommons.org/licenses/by-nd/4.0/

Published by the Centre for Strategic and International Entrepreneurship - Krakow, Poland 
